\title{
ESTABLISHING RELATIONS OF UZBEKISTAN WITH THE UNO AND ITS SPECIALIZED AGENCIES
}

\author{
Nafisa Akhmad Qizi Akhmadova \\ Karshi State University, Uxbekistan
}

\section{ABSTRACT}

Relations between Uzbekistan and the UN and its specialized agencies, mutual exchange historical and cultural dialogue, mutual agreements and treaties were covered and analyzed on the basis of sources. On the basis of mutual agreements, progress has been made in the fields of socio-political and cultural science and education, further prospective plans have been identified.

KEYWORDS: - Diplomatic relations, international cooperation, UNESCO, UNICEF, science and education, scientific and technical, healthcare, tourism culture.

\section{INTRODUCTION}

The UN plays an important role in the relations of the Republic of Uzbekistan with international organizations. From the initial years of independence, Uzbekistan became a member of the United Nations as an equal sovereign representative of the international community and cooperates with the international organizations and its specialized agencies on the issues of international and regional security sustainable development, socio- economic and environmental threats. Uzbekistan is collaborating with the specialized agencies within the UN - the organization of educational, scientific and cultural organization, the world Health Organization, the International Children's Fund, the International Postal Union, the International Telecommunication Union, the World Meteorological Organization, the
International Olympic Committee, the International Automobile Union and as a member of organizations.[1]

The United Nations organizations - An international organization established to promote peace and security on earth. It was created in 1945. The decision to establish the UN was made at the Moscow Council of Foreign Ministers of the USSR, the United States, Britain and China in 1943 and the Charter was adopted at the San Francisco conference in 1945. The UN charter was originally signed by 51 countries and in 2000, their number reached 189. The UN's permanent workplace is New York. [2]

On March 2, 1992, the Republic of Uzbekistan became a member of the United Nations for the first time in its history as an equal subject of the world.This historical went plays an important role in taking a worthy place in the international community as an independent state. The UN's 
CURRENT RESEARCH JOURNAL OF HISTORY 2(6): 76-81, June 2021

DOI: https://doi.org/10.37547/history-crjh-02-06-17

ISSN 2767-472X

(C)2021 Master Journals

\section{Crossref dof 80 Google}

Accepted 25th June, 2021 \& Published 30thJune, 2021

permanent workers on the issues of security, sustainability and collaborating in Tashkent discussed conflicts of Afgan and Tajikistan, fighting against narco business and some other suggestions.[3]

\section{Material AND MEthods}

Taking into account the well- founded comments of the first President of Uzbekistan, UN office was established in Tashkent in February 1993. Khalid Malik has appointed UN representative to Uzbekistan. Today, UN's office in Uzbekistan managed to integrate United Nation Program, industrial development program, the High Commissioner for Refugees, the World Health Organization, the population fund, the Drug Control program, Children's fund and other specialized organizations.

On September 15-16, 1995, at the initiative of Uzbekistan and under the auspices of the United Nations, the Tashkent Council -Seminar on Security and Cooperation in Central Asia was held. Plenipotentiarus from 31 countries and 6 international organizations participating in the International Council discussed the issues of regional security, conflict prevention, building a reliable system of deepening integration processes, expressed their views and suggestions. The Declaration adopted at the end of the Council called on the peoples of the world in particular, the peoples of Central Asia, to strengthen regional security of various political forces, to establish system of economic and environmental cooperation. Another bright page of Uzbekistan's cooperation with the United Nations is the issue of making the Central Asia region a nuclear- weapon free zone. In his speech from the rostrum of the 48th session of the UN General Assembly, the first President of Uzbekistan Islam Karimov put forward the idea of making Central Asia region a nuclear- weapon free zone. The initiative of Uzbekistan was supported by international community. [4]

The 50th anniversary of the United Nations, celebrated in October 1995, and its anniversary session provided opportunity for Uzbekistan to demonstrate its new capabilitus in international politics. The extreme short and concise speech of the first President of our country I.A. Karimov from this prestigious rostrum had a special impact on changing the views of the world community, enriching the activitus of international organizations with new forms and content. The topical issues raised by the first President of Uzbekistan at the 50th session of the United General Assembly that make politicians and statesmen of the world think more seriously, understand the essence of the issues stand on the threshold of the century and look back centuries are not in vain. From this huge rostrum I.A.Karimov first drew the attention of statesmen and politicians to the need to consider the issue of national security in the light of modern requirements and needs. [5]

On September 15-16, 1997, an international conference on "Central Asia- a nuclear weaponfree zone" was held in Tashkent. If was attended by representatives of 56 countries and 16 international organizations. A statement of the Central Asia Foreign Ministries on this issue was signed.

The transformation of Central Asia into a nuclear weapon free zone strengthens its security. In 2000, Tashkent hosted an international conference on strengthening security and stability in Central Asia, the fight against drug trafficking, organized crime and terrorism. At the initiative of the first President of Uzbekistan, a special Committee of the UN Security Council on Combating Terrorism was established in 2001. The visit of the UN Secretary General Kofe Annan to Uzbekistan on October 18-20, in 2002, is a proof of the strengthening of our country's place in an international community and its graving 
CURRENT RESEARCH JOURNAL OF HISTORY 2(6): 76-81, June 2021

DOI: https://doi.org/10.37547/history-crjh-02-06-17

ISSN 2767-472X

(C)2021 Master Journals

\section{Crossref dof 80 Google}

Accepted 25th June, 2021 \& Published 30thJune, 2021

\section{prestige.[6]}

President of the Republic of Uzbekistan Shavkat Mirziyoyev gave a speech at the 72nd session of the United Nations General Assembly on September 19, 2017. In his speech, the President said "The United Nations will continue to be crucial in international relations. Uzbekistan supports the gradual reform of this organization. We believe that the Security Council needs to be expanded to meet today's requirements. We support the efforts taken by the new leadership of the United Nations to improve the governance of the organization. Uzbekistan will continue to cooperate with UN agencies. We will take firm measures to ensure the practical implementation of the "road map" developed by the recent visit of Secretary General Antonio Guterres to Uzbekistan.

Today, Uzbekistan attaches great importance to the Central Asia region in its foreign policy. This is a well- thought- out path. Uzbekistan which is located in the heart of Central Asia is directly interested in the rotation of the region of stability, sustainable development and good neighborliness. We support the full implementation of the special program adopted this fear regarding the practical assistance to the population affects by the Aral Sea tragedy".[7]

On September23, 2020, the President of the Republic of Uzbekistan Shavkat Mirziyoyev addressed the 75th session of the United Nations General Assembly in the uzbek language. Sh. Mirziyoyev noted that for the first time in history, the Session of the UN General Assembly is being held in a completely new format- online due to the coronavirus pandemic. Such a global catastrophe has not been observed on our planet in the last hundred years. This catastrophe clearly showed the weaknesses of all mankind. The current dangerous and difficult situation has proved that all countries and peoples of the world are interconnected and that regular dialogue between us is important for trust and close cooperation, he said.

Recalling the Samarkand international Forum on Youth Rights held under the auspices of the United Nations in August, the President called on the world community to support Uzbekistan's initiative to adopt the United Nations convention on the Rights of the child.

"We propose to adopt a special resolution of the United Nations General Assembly on achieving the Sustainable Development Goals and enhancing the role of parliaments in ensuring human right" said he.[8]

The speech of the President at the UN session shows that the cooperation between the UN and Uzbekistan is enriched in a new way, with new proposals. There are several specialized organizations of the United Nation, one of which is UNESCO.

UNESCO- is an organization which deals with the issue of science, culture and education of United Nations- is an international intergovernmental organization, a specialized agency of the United Nations. It was established in 1946 to promote peace and international security through the development of cooperation between the states in the fields of education, science, culture and communications. 188 countries (including the Republic of Uzbekistan since October 26, 1993) are members. Under the UNESCO Charter, the organization's priority is to promote the cooperation of peoples through the development of education, science and culture in order to ensure. Universal respect for justice, the rule of law, human rights and fundamental freedoms for all peoples, regardless of race, language or religion. About 400 international nongovernmental organizations and foundations, international and regional associations cooperate with UNESCO. The UNESCO budjet consists of contributions from member countries.[9] 
CURRENT RESEARCH JOURNAL OF HISTORY 2(6): 76-81, June 2021

DOI: https://doi.org/10.37547/history-crjh-02-06-17

ISSN 2767-472X

(C)2021 Master Journals

\section{Crossref do) 81 Google}

Accepted 25th June, 2021 \& Published 30thJune, 2021

Cooperation between UNESCO and Uzbekistan has been developing since 1993, when Uzbekistan became a member of this organization. In the early years of independence, these ties were further strengthened. In particular, on November 6. 1998, the final meeting of the 155th session of the UNESCO Executive Board was held in the Amir Temur Hall of the "Intercontinental" Hotel in Tashkent. The 155th session was opened on October 19 in Paris. Its main theme was "the 50th anniversary of the Universal Declaration of Human Right, the duty to remember and the need for vigilance, the number of restoration of human dignity from slavery", in the session. In addition to various organizational issues and a report on the implementation of UNESCO action programs adopted by the UNESCO General Conference, three documents on the development of secular culture were scheduled to adopt. The first document was a comprehensive report on secular culture for the UN the second was an assessment of an interdisciplinary project called "On the path to Secular Culture", which were adopted at the meeting in Paris. The third document was a draft resolution proposed by Uzbekistan entitled "Secular Culture and the Activities of UNESCO in Member states".[10]

The National Commission of the Republic of Uzbekistan for UNESCO, established in December 1994, is actively working to develop this sector in our country. Since 1996, 45 educational institutions of the country have joined the network. These educational institutions have successfully participated in a number of international programs, promoting the goals of "Education for All" and the United Nation Decade for Sustainable Development Education. In addition the organizations activities in the field of education include inclusive education, education in the field of information and communication technologies, public education centers vocational training institutions, covering areas such as healthy lifestyle education.

In 2003, UNESCO declared the 10th Anniversary of Education for Sustainability and Development. In this regard, many events have been held in our country. Within the framework of this program, tasks such as expanding the opportunitus for language learning of the population, the development of education in the field of spirituality and enlightenment, ensuring the under use of scientific and technical achievements have been consistently implemented. The practical result of this good work is the example of our compatriots "Management of water and natural resources" and "Creating an oasis in the desert" projects were found to be the most advanced experience of 2009 in the field of sustainable development education. So far, the national list of intangible cultural heritage of Uzbekistan includes 74 objects. As a unique example of the world heritage, four ancient cities of Uzbekistan Samarqand, Bukhara, Shakhrisabz are included in the UNESKO list, being included in the Representative List of UNESKO as a cultural heritage. Tashkent State the inclusion of the rare manuscripts collected at the Abu Rayhan Beruni Center for Oriental Manuscripts at the Institute of Oriental Studies in the Memory of the world list is the resuet of Uzbekistan's consistent and effective cooperation with this international organization. [11]

UNESKO is actively involved in the preservation and promotion of the rich historical and cultural heritage of the Republic of Uzbekistan. In particular, as of 2017, 5 objects from the Republic of Uzbekistan were included in the UNESCO world Heritage List, which included 1073 monuments of the world [12]; Ichan Qal'a in Khiva in 1990, in 1993 the historical center of Shakhrisabz, the Samarkand crossroads of cultures in 2001 [13], the Western Tien Shan mountain in the joint candidacy of Uzbekistan, Kazakhstan and Krygyzstan in 2016 are included. 
CURRENT RESEARCH JOURNAL OF HISTORY 2(6): 76-81, June 2021

DOI: https://doi.org/10.37547/history-crjh-02-06-17

ISSN 2767-472X

(C)2021 Master Journals

\section{Crossref do) 81 Google}

Accepted 25th June, 2021 \& Published 30thJune, 2021

Uzbekistan has also established cooperation with another UN specialized agency, UNICEF.

Cooperation between this organization and Uzbekistan has been further strengthened during the years of independence.

The United Nations Children's Fund (UNICEF) is one of the main funds of the United Nations. It was founded in 1946 to care for European Children who were facing great hardships as a result of a long war. Since 1953, it has become a permanent member of the United Nations. Its main principle is to promote the healthy and harmonious development of Children on Earth, especially in developing countries. It was awarded the Nobel Prize in 1965 for his work in this field.

After gaining independence, Uzbekistan became a member of UNICEF and established close cooperation with it, the foundation has implemented long-term programs on immunization of children, provision of food and drinking water to primary school students, delivery of vaccines, a special program to assist the population of the Aral Sea region [14].

Government of the Republic of Uzbekistan and UNICEF was signed on December 19, 1994 in Tashkent. This document was ratifud by the Oliy Majlis of the Republic of Uzbekistan on December 22, 1995. The UNICEF office in Uzbekistan was opened on March 1, 1994.

The first State Program between UNICEF and the Republic of Uzbekistan from 1994 to 2000; During 2000-2004, the Second State Program was implemented. According to it $19 \mathrm{mln}$. U.S. dollars were allocated.

On November 30, 2009, the Republic of Uzbekistan and UNICEF signed the Third State Program for 2010-2015. Under this program, UNICEF has increased funding for projects in the country from $\$ 5$ million to $\$ 7$ million per year. UNICEF's total assistance for 2010-2015 is
$\$ 42,234$ million, including \$19,734 million from UNICEF and $\$ 22,5$ million at the expense of donors was made.

UNICEF's activities in Uzbekistan are carried out within the framework of the Fund's state Programs and cover the following areas:

- $\quad$ promotion the welfare of the population;

- $\quad$ protection of motherhood and childhood;

- $\quad$ helping improve the child's life.

On April 15, 2016, the Government of Uzbekistan and the UNICEF office in Tashkent Signed a new state Program for 2016-2020.

This state Program has been developed taking into account the United Nations Development Assistance Framework (UNDAF). The total budjet is $\$ 327$ million.

In short, cooperation between Uzbekistan in the field of UN and its agencies specialized and cultural and humanitarian spheres has been established and they are reflected in such areas as science and technology, education and training. The relations between Uzbekistan and UNESCO are strengthening to this day. Cooperation between Uzbekistan and UNICEF is further developing, many agreements and programs are being signed within the framework of cooperation.

\section{ReFERENCES}

1. Q.Usmonov, M. Sodikov, S.Burkhonova "History of Uzbekistan" T: "Economy finance" 2006, 461p.

2. https://uz.wikipedia. org//wiki United Nations organization.

3. Jurayev N. History of Independent Uzbekistan - T “G'afur G'ulom” 2013. 587p

4. Q.Usmonov, M. Sodikov, S.Burkhonova 
"History of Uzbekistan" T: "Economy finance" 2006, 459p.

5. Jo'rayev N.History of Uzbekistan;(Period of National Independence) T.: Sharq, 2011.$653 \mathrm{p}$.

6. Q.Usmonov, M. Sodikov, S.Burkhonova "History of Uzbekistan" T: "Economy finance" 2006, 459p.

7. Shavkat Mirziyoyev "The consent of our people is the highest assessment to our activities" T. "Uzbekistan" 2018-yil, 246249-pages.

8. https://www.gazeta.uz/oz/2020/09/23/b $\mathrm{mt} /$

9. https://uz.wikipedia.org/wiki/UNESCO

10. Jo'rayev N. History of Independent Uzbekistan. - T.: "Sharq", 2000.- 526 p.

11. https://uzbekistan.lv/uz/ozbekistonunesko-cooperation on the way to peace and goodness.

12. http://whc.unesco.org/?cid=31\&l=en\&\&mo $\mathrm{de}=$ table(27.05.2016)

13. UNESCO Country Programming Document (UCPD) for the Republic of Uzbekistan (2014-2017). UNESCO office in Tashkent.2013. - P.50.

14. https://uz.wikipedia.org/wiki/

15. https://m.mfa.uz/uz/cooperation/internati onal $/ 2113 /$ ?print $=Y$ 